Hamid, I., \& Jena, P.K. (2020). Linear and non-linear Granger causality between foreign direct investment and economic growth: evidence from India. Copernican Journal of Finance \& Accounting, 9(2), 25-44. http://dx.doi.org/10.12775/CJFA.2020.006

\author{
ISHFAQ HAMID* \\ Shri Mata Vaishno Devi University \\ Pabitra Kumar Jena** \\ Shri Mata Vaishno Devi University
}

\title{
LINEAR AND NON-LINEAR GRANGER CAUSALITY BETWEEN FOREIGN DIRECT INVESTMENT AND ECONOMIC GROWTH: EVIDENCE FROM INDIA
}

Keywords: India, economic growth, foreign direct investment \& causality.

\section{J E L Classification: F21, F23.}

\begin{abstract}
The present study tries to understand the association among Foreign Direct Investment (FDI) and Economic growth in India. This paper applies the causality test of Granger (1969) based on the VECM and non-linear causality test of Dike and Panchenko over the period 1993-2016. This study gives a proof about the continuation of a long-run equilibrium association between FDI and Gross Domestic Product (GDP) or Economic Growth for the period being investigated. Unidirectional causality runs from FDI to GDP in the long run. The apparent non-linear causality running from FDI to GDP means that FDI is a policy instrument in stimulating Indian economic growth and provides support for the bi-directional non-linear causal connection between FDI and economic growth with 1, 2 and 4 lags. There has been no definitive investigation as of recently to
\end{abstract}

Date of submission: January 17, 2020; date of acceptance: March 20, 2020.

* Contact information: bhatishfaq260@gmail.com, ICSSR Doctoral Fellow, School of Economics, Shri Mata Vaishno Devi University, Katra, Jammu \& Kashmir, India-182320, phone: 09797025873; ORCID ID: https://orcid.org/0000-0002-9187-877X.

** Contact information: pabitrakumarjena@gmail.com, Assistant Professor, School of Economics, Shri Mata Vaishno Devi University, Katra, Jammu \& Kashmir, India-182320, phone: 09419214167; ORCID ID: https://orcid.org/0000-0002-7746-0916. 
find "linear and non-linear" Granger causality between Foreign Direct Investment and Economic Growth in India" and this study goes a stage advancing and present exact models that can be used to find the association among Foreign Direct Investment and economic growth.

\section{INTRODUCTION}

Foreign Direct Investment is of growing significance in propelling economic growth of any nation. FDI inflows are the necessity of Indian economy. This is because India is the process of transformation from a traditional economy to modern economy. Since the opening of economic reform in India in 1991, real changes have been stated in the field of Joint ventures, exchange of goods and services and commercial sector. As far as reform is concerned, India allows FDI inflows to build up the connection to the world trade and also embraced an amiable foreign policy in order to bring back the assurance of overseas investors. In July 1991, the government has introduced a series of reforms in the trade sector aimed to help the integration of the Indian economy better with the rest of the world. India's FDI equity investment has surged 22\% to USD 35.8 billion in 9 months of 2016-17 in comparison to the corresponding period of 201516.The robust flow of overseas investment indicates that India is economically quite stable. In order to make life easier for the overseas investors, the center has decided to do away with the foreign investment promotion board (FIPB), promising more reforms during the union budget 2017 speech. India comes up with new idea i.e. "Invest India" to collaborate the public and private sector for pulling more FDI in the nation, and this new idea will give information to the host countries regarding investment and also working on no profit and no loss basis (Sen, 2013). In its capital 1000 core, the government and Federation of Indian Chambers of Commerce and Industry (FICCI) have the share of 49:51. Since the onset of globalization, India has progressively adopted liberalized investment policies to facilitate the growth of FDI. FDI is a twofold sword as it cuts the two distinct ways, on one side, it boosts the improvement of an economy. But on the other side, it creates an excursion of capital, which consequently impacts the growth of a host country. Nevertheless, FDI has been perceived as a lesser dissimilarity and become the most vital and strong vehicle for enlivening the improvement of the world economy in common developing and emerging economies in specific. The most appropriate model is the advancement of India and China. While China has come out as the second-most noteworthy re- 
cipient of FDI on the planet overriding the United States, India has in like manner come up as the most preferred location for FDI in the world. Hence, India is the bright spot in the Globe today. Countries like China, Brazil, Argentina, Chile, Thailand, Russia, and Indonesia have allowed 100\% FDI in the retail sector and have benefited a lot. Whereas India has allowed only $51 \%$, that too with various regulations and checks. The Competition Commission of India (CCI) has been setup that looks after the anti-competitive practices and prevents from monopoly pricing. Therefore India provides a conceivable arrangement for all favorable policies to draft more external FDI via removing restrictions on domestic economic policies, foster financial sector development, withdraws restrictions on overseas investment and also provided a favorable environment for overseas investment. FDI shows a vital character in developing nations and also key element that represents the economic integration of the world. They execute as a long term basis of assets as well as a starting point of high and emerging technologies. Overseas investment is non-debt, non-volatile investment and profits received on these investments are by and large spent on the host country itself and therefore helping in the economic development of the country. The government has set up conformity for policy outline on FDI, which is straightforward, predictable and effectively graspable. This structure is alive in the circular of consolidated FDI policy, which is updated from every once in a while to confine and keep pace with the regulatory changes, influenced in the interregnum. The government was hands-on in offering many impetuses such as concessions of tax, generalization of licensing processes and even de-reserving certain businesses to attract FDI inflows into the nation.

This study adds more insights to the previous literature regarding FDI inflows and growth. There is an imperative need for an empirical study that overcomes the homogeneity problem as the earlier studies more focus on cross-sectional scrutiny. The aim of this investigation is to find out the causal association among FDI inflows and GDP in India.

\section{REVIEW OF LITERATURE}

There exist clashing confirmations in the literature with respect to the FDIgrowth relationship. Bailliu (2000) find out the impact of financial development and FDI inflows on growth in developing countries. The empirical finding shows that there is affirmative and significant effect of capital flows on 
economic growth; if the internal sectors has reached the minimum standard of development. Nair-Reichert and Weinhold (2001) applied causality for 24 countries using data for the period 1971 to 1995. Although they give more emphasis to heterogeneity as a grave issue and consequently, use the mixed fixed and random effect approach so as to verify or test the impact of FDI on growth. Kumar and Pradhan (2002) conducted a study to find out the relationship between FDI inflows and domestic investment in 107 developed countries over the period 1980-99. The findings of this study show that FDI inflows have a negative impact on domestic speculation in a larger way and the consequent beneficial outcomes for the panel approach as for the greater part of the countries independently. A study conducted by Holtz-Eakin, Newy and Rosen (1988) for 80 nations showed a bi-directional causality amongst FDI and economic growth. Hansen, Rand and Tarp (2009) took sample of a 31 developing nations and applied estimators for heterogeneous panel data, establish a bi-directional causality amongst FDI/GDP and the level of GDP. In this study result support in favors the hypothesis that FDI effect GDP through transfers of skills and implementation of new innovation. Li and Liu (2005), used panel data for 84 countries during the period 1970-1999 and found that FDI has a link with the human capital base that gives better outcome on economic growth and development of developing countries. And also, relations of FDI with technological gap have a negative sway. Johnson and Robinson (2005) find out the competence of FDI inflows to impact host country economic growth over the period 1980-2002, using panel data approach for a sample of 90 countries. The findings of the investigation show that FDI inflows positively affect financial development because of innovation overflow and capital streams. Moreover, the results show that FDI improves financial development in developing nations, however not in developed nations. Ramirez (2006) find out the effect of FDI inflows on the economy of Mexican during the period 1960-2001, using time series techniques. The findings of the study show that FDI inflows bring favorable impact on the productivity of labor due to better-advanced skills and efficient administrative capabilities, which will impact the host nations in positive dimensions. In (2007) Duasa conducted a study on Malaysia to find out the causal connection between the chosen variables. The findings of the study shows that there is no causal association among the variables, therefore that means FDI doesn't bring growth and that a different way around. Magnus and Fosu (2011) find out the causal association between FDI and GDP growth in Ghana for the 
period 1970-2002, using time series techniques. The findings of this empirical study show that there is no causal link between these two variables throughout the model. Moreover, this study also shows that FDI affected GDP growth in the passage of the Post-SAP era. In addition a study conducted by Dubé, Hitsch and Rossi (2009) which finding that FDI inflows don't always have a positive impact on development because it bases losses in the form of bonuses, revenues, and interest. Kinda (2010) finds that lack of physical infrastructure; financial constraints, low level of technology and uncreative environment reduce FDI in developing nations. For instance, an absence of internet connectivity, electricity crises, poor access to credit, absence skilled workers have a negative impact on FDI in developing nations. Agrawal and Khan (2011) in their study found that developing countries facing the problem of the saving-investment gap, and also found that FDI has a favorable effect on economic growth due to knowledge transfer, creative technology, employment creation and expanding rivalry. Karagianni (2012) investigated the non-linear causality among tax encumbrance circulation and per capita GDP. This study divulges that GDP growth has dominant part of the tax encumbrance across tax-answerable clutches in the economy of USA. In 2012, a study conducted by Ludosean in Romania using vector autoregressive model of time series techniques. The results of the study show that FDI and economic growth has no causal link, but causality stays consecutively from economic growth to FDI. Popescu (2014) shows that FDI inflows has vital character in factors of production (i.e. land, labour and capital) for host nations. These factors are important for growth of an economy and exemplifies positive connotation among FDI and economic growth. In another study Vogiatzoglou and Nguyen (2016) applied co-integration test of Johansen which shows that there is long-run connection among the variables which we have taken in this study. But it is not necessary that Johansen co-integration support the hypothesis of FDI-led growth without ascertaining core compelling variables that basis the co integrating association to clench. As far Tomi and D'Estaing (2015) using ARDL model to find out the association between FDI and GDP in 7 European countries from 1970-2012. The result shows that FDI and economic growth has insignificant association. Furthermore, Ndiyan and Xu (2016) using Panel ordinary least square and Fixed Effect over the period from 1990-2012 in 7 WAEMU countries. The outcome of the regression shows that FDI and GDP has negative affiliation. Adams and Klobodu (2017) results show that there is significant and positive connection among FDI and 
GDP in Burkina Faso by using ARDL Model over the period 1970-2014 in 5 SSA countries. Sothan (2017) applied Autoregressive Distributed Lag Model to find out the relationship between FDI inflows and GDP over the period 1984-2017 in Cambodia, and found that FDI has a crucial eccentric in economic growth, and bilateral relation exists between FDI inflows and GDP respectively. Recently, Sengupta and Puri (2018) have used an OLS regression to scrutinize the influence of FDI Inflows on GDP. They found that FDI inflows have positive impact on economic growth through well-equipped technology and knowledge transfer. In addition, Nguyen, Tham, Khatibi and Azam conducted study in Africa (2019) tested the FDI- led growth Hypothesis during the period from 1995-2014. The findings of the study display that FDI Inflows stimulates GDP of the host nation through the stock of capital, job creation, and technology transfer.

The above literature demonstrates that an all-inclusive closure on the growth impact of FDI can't have come. This concludes that the effect of FDI inflows on Economic growth are at a standstill debatable.

\section{FDI AND ECONOMIC GROWTH IN INDIA}

The occurrence of multinational companies in developing countries plays a vital role in uplifting the domestic economy due to their technical skills, better administrative policies and managerial capabilities. But on the other side, MNE's enter various exports in the domestic market which indirectly helps the host market because it provides information about the foreign market and also improves the infrastructure base in the host country (UNCTAD, 2000). Concerning of developing countries, in particular, worldwide pragmatic work is done on the FDI - growth nexus and has shown that subject to the number of vital factors, such as infrastructure base in the host country, financial stability, and cost of capital and trade openness in the economy. From the Innovation point of view, FDI empowers financial development and economic growth which spreads the advantages everywhere in the economy. It also shows a dynamic role in economic development and one of the important sources is the transfer of technology from developed to developing nations. It has numerous effects that contribute to economic development through opportunities of employment, upliftment of capital formation, and betterment of management skills. FDI inflows stand out as the most critical engine for economic growth in developing nations (Solow, 1956). During the process of trade liberalization, 
a country lifts its trade barrier and therefore, a major component of liberalization became trade openness and FDI. Hence, these variables played an imperative role in the process of economic growth in the liberalized countries. In 1991, the government of India comes up with a liberalization policy. The purpose of this policy is to initiate privatization, various tax reforms, and deregulation and open the Indian economy with the rest of the world for investment purposes. Accordingly, it means that reformation of earlier regimes of trade and provides them better assimilation with the rest of the world by and large.

Figure 1. GDP per capita (in US\$) of India



S o u r c e : UNCTAD.

Figure 1 reveals the GDP Per capita for India. It can be observed that GDP Per capita increased slowly from 1993 to 2016. In 2016, India GDP Per capita stands at approximately US $\$ 1709.39$ which specifies that among BRICS nations, India has the bottommost GDP Per capita. 
Figure 2. FDI net inflows of India



S o u r c e : UNCTAD.

Figure 2 provides information regarding FDI net inflows of India. India attracted a significant amount of FDI after Industrial Policy 1991 because its main objective was to transform India into a major partner and players in the global arena. FDI net inflows of India increased from US\$ 2378.68 to US\$ 43478.27 in 2016.

\section{THE RESEARCH METHODOLOGY AND THE COURSE OF THE RESEARCH PROCESS}

This study used annual data during the period 1993-2016, containing 21 years as a sample period. The variables which have taken for this study are FDI net inflows and GDP per Capita and the data is collected from World Bank (2019). To scrutinize the causal link between FDI and growth, we used the causality test of Granger (1969) and Lutkepohl. H (1982). The main aim of the authors behind this model is to find out the application of causality in economic science. It is basically a hypothesis test for choosing whether a one-time series is useful in predicting another. Moreover, the "standard Granger causality test" in economics could be tested by measuring the ability to forecast the forthcoming value of a time series using the prior value of another time series. Furthermore, this technique provides evidence given by one variable in amplification the latest value of additional factor. Similarly, it also says that factor $Y$ is caused by factor $\mathrm{X}$ if factor $\mathrm{X}$ helps with foreseeing the estimation of factor $\mathrm{Y}$. By and large, time-series information follows a specific pattern, and the theory of economics necessitates that they are exposed to differencing or de-drifting dealings, otherwise fake outcomes will be acquired (Gujarati, 1995). 


\section{UNIT ROOT TEST}

The stationary of the data is the necessary step for sketch gist full interferences in a time series analysis. For that, we apply unit root test which tells us whether the series is stationary or not. Furthermore, in this study we use one of the recognized test among unit root tests namely (ADF) test. The more negative it is, the stronger the rejection of the hypothesis. The testing procedure for estimating the regression equation is:

$$
\Delta \mathrm{X}_{\mathrm{t}}=\alpha+\rho \mathrm{t}+\beta \mathrm{X}_{\mathrm{t}-1}+\sum_{\mathrm{i}=1}^{\mathrm{k}-1} \gamma \mathrm{i} \Delta \mathrm{X}_{\mathrm{t}-\mathrm{i}}+\varepsilon_{\mathrm{t}}
$$

Where $\alpha$ is the constant term; $\rho$ shows coefficient of time pattern; $X$ is the variable under scrutiny. We incorporate empirical analysis for both the factors with $\log$ form. $\Delta$ is the operator of first difference; t shows trend of time; and is a disturbance of the model. The unit root test is done on the (xt-1) coefficient in the overhead regression. Furthermore, if the $\beta$ coefficient is seen as statistically unique in relation to zero $(\beta \neq 0)$, the $\left(\mathrm{H}_{0}\right)$ "null hypothesis" that the factor $\mathrm{x}$ encompasses a unit root issue is exempted, inferring that the factors doesn't have a unit root. The "lag" similarly resolve in the ADF and is chosen to employ (AIC).

\section{JOHANSEN COINTEGRATION TEST}

This study is an attempt to apply the cointegration test of Johansen in order to establish the long-run associations between the variables which we have taken, we also used the causality test of Granger which tells us the direction of the relationship among the proposed variables. Moreover to accomplish better outcomes from this very test, choosing the "optimal lag length" is so essential. The cointegration test of Johansen proceeds its foundation from the origin in the "Vector Auto-Regressive model" of order $\mathrm{p}$ is anticipated by:

$$
Y_{t}=A_{1} y_{t-1}+\cdots+A_{\rho} y_{t-\rho}+B_{X t}+\varepsilon_{t}
$$


Where $y_{t}$ is a vector of endogenous variables; $A$ signifies the autoregressive matrices; $X_{t}$ shows the deterministic vector; $B$ denotes the parameter matrices; $\epsilon_{t}$ is a vector of innovation and $\rho$ is the lag.

The VAR can be modified as:

$$
\Delta \mathrm{Y}_{\mathrm{t}}=\Pi \mathrm{Y}_{\mathrm{t}-1}+\sum_{\mathrm{i}=1}^{\rho-1} \mathrm{~T} \mathrm{i} \Delta \mathrm{Y}_{\mathrm{t}-\mathrm{i}}+\mathrm{B}_{\mathrm{xt}}+\varepsilon_{\mathrm{t}}
$$

In equation 3 , the matrix sign " $\Pi$ " provides the evidence on the coefficient of long-run of the $Y_{t}$ variables in the vector. However, at order one if all the dependent variables in $Y_{t}$ are co-integrated, the rank " $r$ " is supposed by the rank of $\Pi=\alpha \beta$. Sign $\alpha$ shows the declining comparison of the measurement in the VEC model and $\beta$ indicates the parameters of the matrix of the co-integrating vector.

Two appropriate likelihood Ratio (LR) test measurements are used to find out the co-integrating ranks and vectors, namely, the first one is trace statistics and another is maximum Eigenvalue. The first statistical test tests the $\left(H_{0}\right)$ means that the amount of the distinctive co-integrating vector is fewer than or equivalent to ", $\mathrm{r}$ " in contradiction of the $\left(H_{1}\right)$ of $\mathrm{K}$ cointegrating associations, $\mathrm{K}$ shows the number of independent factors, for $\mathrm{r}=0,1 \ldots \mathrm{K}-1$. The $\left(H_{1}\right)$ of $\mathrm{K}$ cointegrating associations resembles the circumstance wherever the series does not have a unit root. The maximum Eigenvalue test tests the $\left(H_{0}\right)$ means that cointegrating vector quantity is $r$, against the $\left(H_{1}\right)$ of $1+r$ cointegrating vectors.

\section{GRANGER CAUSALITY BASED ON THE VECM}

In order to find out the long-run association among the variables which we have taken in this study, we used the cointegration test of Johansen. After that if the series are co-integrated, we apply the causality test of (Engle \& Granger,1987) based on VECM, which is the best approach to find out the short and long-run associations, based on the subsequent forms: 


$$
\begin{aligned}
& \Delta \log (\mathrm{GDP})_{\mathrm{t}}=\beta_{1, \mathrm{t}}+\sum_{\mathrm{j}=1}^{\mathrm{n}-1} \beta_{11}, \mathrm{j} \Delta \log (\mathrm{GDP})_{\mathrm{t}-\mathrm{j}}+\sum_{\mathrm{j}=1}^{\mathrm{n}-1} \beta_{12}, \mathrm{j} \Delta \log (\mathrm{FDI})_{\mathrm{t}-\mathrm{j}} \\
& +\delta 1 \mathrm{EC}_{\mathrm{t}-1}+\mu_{1 \mathrm{t}} \\
& \Delta \log (\mathrm{FDI})_{\mathrm{t}}=\beta_{2, \mathrm{t}}+\sum_{\mathrm{j}=1}^{\mathrm{n}-1} \beta_{21}, \mathrm{j} \Delta \log (\mathrm{FDI})_{\mathrm{t}-\mathrm{j}}+\sum_{j=1}^{n-1} \beta_{22}, \mathrm{j} \Delta \log (\mathrm{GDP})_{\mathrm{t}-\mathrm{j}} \\
& +\delta 2 \mathrm{EC}_{\mathrm{t}-1}+\mu_{2 \mathrm{t}}
\end{aligned}
$$

Our main focal point is on equation 1, where (GDPlog) and (FDIlog) show the normal logarithms of real GDP per capita and FDI correspondingly. $\mathrm{EC}_{t}{ }_{1}$ shows the coefficient which tells us about long-run causality and the collective $F$ test confirms causality of short-run of the first-differenced independent factors. $\Delta$ is the operator of the first difference. $\mu_{1 t} \& \mu_{2 t}$ are error terms for the model (4) and (5), respectively. $n$ shows the VAR order, which is converted into the lag of $n-1$ in the ECM. $\delta_{1}$ and $\delta_{2}$ indicates the long-run coefficient of Granger causality. In Equation (4), $\beta_{12}$ displays the lagged valve coefficient, $j$ for $j=1 \ldots \mathrm{n}-1$ which indicates the short-run effect of FDI on GDP. In Equation (5), $\beta_{22}$ also displays the lagged value coefficient, $j$ for $j=1 \ldots n-1$ signify the short-run impact of GDP on FDI. In this empirical study Wald test of the collective importance of lags of the independent variables, resolute the case of causality in short-run, which is called as Granger causality based on VECM.

\section{EMPIRICAL ANALYSIS AND DISCUSSIONS}

In this part, the empirical findings of the stationary test, cointegration test and causality test in light of the VECM are applied. Several economic studies are brought into being with non- stationary, however some are stationary. Hence stationary of the variables is important to evade bogus outcomes for policy purposes, the result of standard Augmented Dickey-Fuller test is presented in table 1. 
Table 1. Augmented Dickey-Fuller result

\begin{tabular}{|l|c|c|}
\hline \hline \multicolumn{1}{|c|}{ Series } & Level & First difference \\
\hline \hline $\log (\mathrm{FDI})$ & -2.486 & -4.676 \\
\hline $\log (\mathrm{GDP})$ & -4.107 & -6.757 \\
\hline
\end{tabular}

*Denotes significance at $1 \%$ level.

S o u r c e : author's own calculation using E-views .

The outcome of this test confirms that all the data are found to be non-stationary at the level, $1(0)$, then we go for $1(1)$ i.e. first differencing. But the null hypothesis $\left(\mathrm{H}_{0}\right)$ of both the variables is precluded for the persistence of unit root, concluded that both the variables which we have taken are significant at 1(1). The outcome demonstrates that the cointegration method of Johansen is a proper procedure used to crisscross regarding the factors of cointegration.

To make use of the cointegration test of Johansen, the initial step is that, variables must be non-stationary at level but when we convert all the variables into the first difference, then they will become stationary and both the variables should be significant at the same level. Then after deciding the lag selection for the mechanism of VEC. Furthermore, the quantity of lag selection is founded on the maximum value of AIC outcomes of the "bivariate Johansen cointegration tests" which are undertaken in table 2 .

Table 2. Johansen's cointegration result

\begin{tabular}{|c|c|c|c|c|c|}
\hline $\operatorname{Null}\left(\mathrm{H}_{0}\right)$ & Alternative $\left(\mathrm{H}_{1}\right)$ & $\Lambda$ trace & $95 \% \mathrm{cv}$ & $\wedge \max$ & $95 \% \mathrm{cv}$ \\
\hline \multicolumn{6}{|c|}{ Model :Y=[log(FDI), $\log (F D I)]$} \\
\hline$r=0$ & $r \geq 1$ & 17.18828 & 15.49471 & 15.97562 & 14.2646 \\
\hline$r \leq 1$ & $r \geq 2$ & 1.212658 & 3.841466 & 1.212658 & 3.8414 \\
\hline
\end{tabular}

*Denotes the significance at the $1 \%$ level.

S o u r c e : author's own calculation using E-views 10.

From the above model, we find that both the tests i.e. trace test and maximum Eigen valve test are statistically significant and also greater than the critical valve which means that the of no cointegration is disallowed by both the tests 
in the model. The outcome of this study gives validation of long-run equilibrium affiliation among FDI and GDP for the period being investigated.

When we further proceed to find out the track of causality, we go through a Granger causality test which is centered on the VECM. This study mainly emphasis the bivariate Granger causality analysis to find out the pivotal effect of FDI on India's financial growth. The main focus of this study is mainly on FDI because it shows a vital part in the development and progression of the Indian economy. Therefore we proceed our analysis by using the bivariate Granger causality test. The outcome of table 3 presents Granger causality analysis.

Table 3. Granger causality result

\begin{tabular}{|l|c|c|c|}
\hline \hline \multicolumn{1}{|c|}{ Dependent Variables } & \multicolumn{2}{c|}{ Short run } & Long run \\
\hline \hline Model:Y=[log(FDI), log (GDP)] & $\Delta \log (\mathrm{FDI})$ & $\Delta \log (\mathrm{GDP})$ & $\mathrm{Ec}(\mathrm{t}-1)$ \\
\hline$\Delta \log (\mathrm{FDI})$ & 1.0000 & - & 3.35554 \\
\hline$\Delta \log (\mathrm{GDP})$ & - & 2.378541 & -2.92763 \\
\hline \hline
\end{tabular}

*Denotes the significance at the $1 \%$ level.

S o u r c e : author's own calculation using E-views 10.

In this study both the variables are cointegrated at 1(1) and causality can bifurcated into two portions, short and long-run. $\mathrm{EC}_{t}{ }^{-}{ }_{1}$ shows the coefficient which tells us about long-run causality and the collective $F$ test confirms causality of short-run of the first-differenced independent factors, which is imitative from the Wald Test. This study further checking robustness of the model through diagnostic tests.

Table 4. Diagnostic test

\begin{tabular}{|c|c|}
\hline \hline & Model \\
\hline \hline$R^{2}$ & 0.544 \\
\hline Adj, $R^{2}$ & 0.392 \\
\hline DW & 1.194 \\
\hline SE & 0.028 \\
\hline
\end{tabular}


Table 4. Diagnostic...

\begin{tabular}{|c|c|}
\hline \hline & Model \\
\hline \hline Breusch-Godfrey serial correlation LM test: & 0.826 \\
\hline AR/MA (2) & 0.949 \\
\hline AR/MA (1) & 0.163 \\
\hline Heteroscedasticity test:Breusch-Pagan-Godfrey & \\
\hline
\end{tabular}

S o u r c e : author's own calculation using E-views 10.

Before we carry the Granger causality test, it is very essential that our projected model is consistent and free from any bias. The outcome of above table shows that there is no serial correlation and Heteroscedisticity ( $P>0.05)$, meaning that the residuals of the model are normally distributed. However, when we go through the results of table 3 , we find that there is a negative and significant association among the long-run coefficient of GDP and FDI at a 1\% level of significance. But in the situation of the FDI equation, the inverse is true. Furthermore, in the short run, there is no causal link between the given variables.

The findings of this study show that in the long run, unidirectional causality is successively from FDI to GDP. Also, our results found that in long-run FDI plays a vital role in the economic growth of India. These results are consistent with some of the earlier studies done by researchers Ramírez (2000), Fedderke and Romm (2006), Vogiatzoglou and Nguyen (2016), and Tan and Tang (2016) who give solid proof on the pivotal effect of FDI on development in the nations underneath their analysis. Though, few research studies are unreliable with this study (e.g. Belloumi, 2014; Chakraborty \& Basu, 2002; Kakar \& Khilji, 2011; Ludosean, 2012). In this way, we can sum up the debate that this relation is still dubious.

\section{NON-LINEAR GRANGER CAUSLITY APPROACH}

To find out the impact of non-linear Granger causality, we used Diks and Panchenko's (2006) framework of the nonparametric approach for the earlier residuals of the assessed VAR model. However, using non-linear Granger causality test provides more validation regarding the causality association be- 
tween the variables. Furthermore, our purpose is to find out more validation that assists to forecast the total distribution of the given variables. From the above Granger causality explanation, Diks and Panchenko (2006) contend that Granger causes if for $\mathrm{S}>1$ :

$$
\left(Y_{t+1, \cdots,}, Y_{t+s}\right) \mid\left(\mathrm{I}_{\mathrm{xt}}, \mathrm{I}_{\mathrm{yt}}\right) \sim\left(\mathrm{Y}_{\mathrm{t}+1, \cdots,} \mathrm{Y}_{\mathrm{t}+\mathrm{s}}\right) \mathrm{I}\left(\mathrm{I}_{\mathrm{yt}}\right)
$$

$\mathrm{I}_{\mathrm{Xt}}$ and $\mathrm{I}_{\mathrm{Yt}}$ provide the evidence of the previous and present observation of $\mathrm{X}_{\mathrm{t}}$ and $\mathrm{Y}_{\mathrm{t}}$, correspondingly and $\sim$ indicates equality in circulation.

At this instant contemplate $\mathrm{X}^{\mathrm{lx}}{ }_{\mathrm{t}}=\left(\mathrm{X}_{\mathrm{t}-\mathrm{lx}-1}, \ldots, \mathrm{X}_{\mathrm{t}}\right)$ and $\mathrm{Y}_{\mathrm{t}}^{\mathrm{lx}}=\left(\mathrm{Y}_{\mathrm{t}-\mathrm{x} x-1}, \ldots, \mathrm{Y}_{\mathrm{t}}\right)$ for lx,ly>1.If $s=1$, then the $\left(H_{0}\right)$ hypothesis of the Granger causality test can be inscribed as follows:

Ho: $Y_{t+1} l\left(X_{t}^{l x} ; Y_{t}^{l y}\right) \sim Y_{t+1} \mid Y_{t}^{l y}$

Assume $\mathrm{Z}_{\mathrm{t}}=\mathrm{Y}_{\mathrm{t}+1}$, then we have an invariant distribution vector $\mathrm{K}_{\mathrm{t}}=\left(\mathrm{X}^{\mathrm{lx}}{ }_{\mathrm{t}}, \mathrm{Y}^{\mathrm{ly}}{ }_{\mathrm{t}}, \mathrm{Z}_{\mathrm{t}}\right)$. By supposing $l_{x}=l_{y}=1$ and reducing the time indexes for easiness, the combined and peripheral probability density purposes, under the $\left(H_{0}\right)$, should accomplish the subsequent relation:

$$
\frac{f x, y, z(X, Y, Z)}{f y(y)}=\frac{f x, y(x, y)}{f y(y)} \ldots \frac{f y, z(y, z)}{f y(y)}
$$

Consequently, it can be revealed that $\left(H_{0}\right)$ can be articulated as:

$$
E\left[f_{x, y, z}(x, y, z) f_{y}(y)-f_{x, y}(x, y) f_{y, z}(y, z)\right]=0
$$

This leads to the following test statistics. 


$$
\mathrm{T}_{\mathrm{n}(\mathrm{e})}=\frac{\mathrm{n}-1}{\mathrm{n}(\mathrm{n}-2)} \Sigma\left(\hat{\mathrm{f}}_{\mathrm{x}, \mathrm{y}, \mathrm{z}}(\mathrm{xi}, \mathrm{yi}, \mathrm{zi}) \hat{\mathrm{f} y}\left(\mathrm{y}_{\mathrm{i}}\right)-\hat{\mathrm{f}}_{\mathrm{x}, \mathrm{y}}\left(\mathrm{x}_{\mathrm{i}}, \mathrm{y}_{\mathrm{i}}\right) \mathrm{fy}, \mathrm{z}\left(\mathrm{y}_{\left.\left.\mathrm{i}, \mathrm{i}_{\mathrm{i}}\right)\right)}\right)\right.
$$

Where, $\mathrm{fx}, \mathrm{y}, \mathrm{z}(\mathrm{x}, \mathrm{y}, \mathrm{z})$ is the joint probability density function, For $\mathrm{lx}=\mathrm{ly}=1$ and if $\varepsilon_{\mathrm{n}}=\mathrm{Cn}-\beta(\mathrm{C}>0,1 / 4<\beta<1 / 3)$, Diks and Panchenko (2006) prove that the test statistics in equation (10) satisfies the following:

$$
\sqrt{n} \frac{(\operatorname{Tn}(\mathrm{e})-\mathrm{q})}{S n} \rightarrow N(0,1)
$$

Where $\mathrm{q}$ and $\mathrm{S}_{\mathrm{n}}$ are the estimators of asymptotic expectation and standard error respectively.

This study also used (NLDP) test of causality to find out the non-linear relation between GDP and FDI. Table 5 shows the outcomes of the given variables and applied for $\mathrm{lx}=\mathrm{ly}=1 \ldots .5$ and $\varepsilon_{\mathrm{n}}=1.5$. set conferring to the time series length $\mathrm{n}^{5}$.

\begin{tabular}{|c|c|c|c|c|}
\hline \multirow{2}{*}{$\mathrm{Lx}=\mathrm{Ly}$} & \multicolumn{2}{|c|}{ FDI $\longrightarrow$ GDP } & \multicolumn{2}{|c|}{ GDP $\longrightarrow$ FDI } \\
\hline & T Statistics & P-valve & T Statistics & P-valve \\
\hline 1 & 1.498 & $0.05421^{*}$ & 1.452 & $0.05432 *$ \\
\hline 2 & 1.732 & $0.02432 *$ & 1.331 & $0.08763^{* *}$ \\
\hline 3 & 1.356 & $0.06175^{* *}$ & 1.243 & $0.09564^{* *}$ \\
\hline 4 & 1.613 & $0.04821^{*}$ & 1.852 & 0.12783 \\
\hline 5 & 1.139 & 0.16372 & 1.564 & 0.77298 \\
\hline
\end{tabular}

Table 5. Non-linear causality test results in India (Sample period 1993-2016)

N o t e : The null hypothesis suggests that FDI does not cause GDP and GDP does not cause FDI, respectively.

$\left.*^{* *}\right)$ denotes test are significant at $5 \%$ and $10 \%$ respectively.

S o u r c e : author's own calculation using E-views 10.

This study using the DP test on time series of two variables i.e. $X$ and $Y$ and fixed the lag length which is equal for both the variables, specifically $L x=L y$, and then 
afterward we proceed the common lag length of 1-5. The outcome of this test comprises both probability refutation and t-statistics at every lag length for India which are shown in table 5 .

Looking at the empirical findings, bidirectional causality is detected between FDI and GDP. As table 5 indicates there is evidence for a non-linear feedback between FDI and GDP since the test statistics is statistically significant for either $5 \%$ or $10 \%$. The finding also provides support for the existence of a bidirectional non-linear causal affiliation between FDI and GDP, with 1, 2, and 4 lags. The apparent non-linear causality running from FDI and GDP means that FDI is a policy instrument in stimulating Indian economic growth of questionable effectiveness though due to the inexplicit way that economic growth is affected. Moreover, the reverse non-linear causality from GDP to FDI uncovers a non-proportional burden, reallocation and faulty system triggered by the economic growth changes that further complicates the crescendos of the FDI and GDP connection.

\section{ConCLUSIONS}

FDI is the backbone of developing countries like India. They attain a long term basis of capital as well as a basis of superior and developed technologies. The government of India initiates a liberalization policy in 1991, which made quick walks towards joining with world economies and also wider cooperation's with them. The non-linear causality testing approach employed in this study uncovers the non-linear high power causal dependence of the Indian FDI and GDP. Consequently, better policies and suitable environment motivating foreign investors and the government should more focus towards core infrastructure sectors so as to enhancement countrywide struggles. Thus the FDI, booster was seen as a last-minute cure to the worsening economic conditions of the country. India needs FDI and the planners and policymakers should not be obsessed with where it is coming from and which sector it is going into.

In India, there are numerous studies that have been carried out in order to understand the influence of FDI on economic growth across the nation. Whereas various studies support the association between FDI and growth and a very small number of studies undertaken by researchers do not support this association amongst the two variables. We go through numerous studies where grow th impact is not completely known; therefore we choose this study for car- 
rying out with an endeavor and energy to know the causal association between FDI and economic growth. In an outlook of the result of this work, FDI enhances Indian economic growth by enlarging corporeal capital, which is necessarily required for the economic development of the country. Similarly, the growth factor in India itself is not to create an essential role in pull towards more inward FDI. This work is done to keep in mind for the pace of- new insights on the growth impact of FDI in India. Policymakers of developing countries should frame those policies which are people-centric and also draw more attraction towards inward FDI. To focus for more lure of internal FDI, the Government of India should improve the financial sector development and provide a congenial environment for trade and investment, removing restrictions against inward FDI and also develop corporal infrastructure.

In adding up, the policymakers of India should not fail to remember the importance of the development of human capital, because these variables stand for the assimilation aptitude of the economy. Similarly, speedy legislation for land purchase, adjournment of general Anti-Avoidance rules and trim down accessible rate in respect of royalty and fees for industrial services by firms. Political stability must be kept up in light of the fact that it may be the supreme essential donor of FDI and growth in this nation. On the off chance that political stability does not occur; it may adversely influence the economy by and Large. To sum up, we can say that policymakers and researchers should well know of the flaws of the standard linear Granger causality test while dealing with causal relationship between GDP as the objective measure of performance of the economy and FDI as an effective vehicle for the mobilization of financial resources.

\section{REFERENCES}

Adams, S., \& Klobodu, E.K.M. (2017). Capital flows and the distribution of income in sub-Saharan Africa. Economic Analysis and Policy, 55, 169-178.

Agrawal, G., \& Khan, M.A. (2011). Impact of FDI on GDP: A comparative study of China and India. International Journal of Business and Management, 6(10), 71.

Bailliu, J. N. (2000). Private capital flows, financial development, and economic growth in developing countries. Ottawa: Bank of Canada.

Belloumi, M. (2014). The relationship between trade, FDI and economic growth in Tunisia: An application of the autoregressive distributed lag model. Economic Systems, 38(2), 269-287. 
Chakraborty, C., \& Basu, P. (2002). Foreign direct investment and growth in India: A cointegration approach. Applied Economics, 34(9), 1061-1073.

Dickey, D.A., \& Fuller, W.A. (1981). Likelihood ratio statistics for autoregressive time series with a unit root. Econometrica, 49(4), 1057-1072.

Diks, C., \& Panchenko, V. (2006). A new statistic and practical guidelines for nonparametric Granger causality testing. Journal of Economic Dynamics and Control, 30(10), 1647-1669.

Duasa, J. (2007). Malaysian foreign direct investment and growth: Does stability matter. Journal of Economic Cooperation, 28(2), 83-98.

Dubé, J. P., Hitsch, G.J., \& Rossi, P.E. (2009). Do switching costs make markets less competitive? Journal of Marketing Research, 46(4), 435-445.

Engle, R., \& Granger, C. (1987). Co-integration and error correction: Representation, estimation, and testing. Econometrica, 55(2), 251-276.

Fedderke, W., \& Romm, T. (2006). Growth impact and determinants of foreign direct investment into South Africa, 1956-2003. Economic Modelling, 23(5), 738-760.

Granger, C. W. (1969). Investigating causal relations by econometric models and crossspectral methods. Econometrica: Journal of the Econometric Society, 37(1969), 424$-438$.

Gujarati, D.N. (1995). Basic Econometrics: International Edition. New Jersey: PrenticeHall International.

Hansen, H., Rand, J., \& Tarp, F. (2009). Enterprise growth and survival in Vietnam: Does government support matter? The Journal of Development Studies, 45(7), 1048-1069.

Holtz-Eakin, D., Newey, W., \& Rosen, H.S. (1988). Estimating vector auto regressions with panel data. Econometrica: Journal of the Econometric Society, 1371-1395.

Johnson, S., \& Robinson, J.A. (2005). Institutions as a fundamental cause of long-run growth. Handbook of economic growth, 1, 385-472.

Kakar, Z., \& Khilji, B. (2011). Impact of FDI and trade openness on economic growth: A comparative study of Pakistan and Malaysia. Theoretical and Applied Economics, 11(564), 53-58.

Karagianni, S. (2012). Tax burden distribution and GDP growth: Non-linear causality considerations in the USA. International Review of Economics \& Finance, 21(1), 186$-194$.

Kinda, T. (2010). Investment climate and FDI in developing countries: firm-level evidence. World development, 38(4), 498-513.

Kumar, N., \& Pradhan, J.P. (2002). FDI, externalities and growth in developing countries: some empirical explorations and implications for WTO negotiations on investment. RIS Discussion Paper, (27).

Li, X., \& Liu, X. (2005). Foreign direct investment and economic growth: An increasingly endogenous relationship. World Development, 33(3), 393-407.

Ludosean, B.M. (2012). A VAR analysis of the connection between FDI and economic growth in Romania. Theoretical and Applied Economics, 19(575), 115-130.

Lütkepohl, H. (1982). Non-causality due to omitted variables. Journal of Econometrics, 19(2-3), 367-378. 
Magnus, F.J., \& Fosu, O.A.E. (2011). On the Predictability of Inflation Rate in Ghana: A Box-Jenkins Approach. International Journal of Economic Perspectives, 5(1).

Nair-Reichert, U., \& Weinhold, D. (2001). Causality tests for cross-country panels: A new look at FDI and economic growth in developing countries. Oxford Bulletin of Economics and Statistics, 2, 153-171.

Ndiaye, G., \& Xu, H. (2016). Impact of foreign direct investment (FDI) on economic growth in WAEMU from 1990 to 2012. International Journal of Financial Research, 7(4), 33-43.

Nguyen, H., Tham, J., Khatibi, A., \& Azam, S. (2019). Enhancing the capacity of tax authorities and its impact on transfer pricing activities of FDI en-terprises in Ha Noi, Ho Chi Minh, Dong Nai, and Binh Duong province of Vietnam. Management Science Letters, 9(8), 1299-1310.

Popescu, G.H. (2014). FDI and economic growth in Central and Eastern Europe. Sustainability, 6(11), 8149-8163.

Ramírez, M. (2000). Foreign direct investment in Mexico: A cointegration analysis. The Journal of Development Studies, 37, 138-162.

Ramirez, M.D. (2006). Economic and institutional determinants of foreign direct investment in Chile: A time-series analysis, 1960-2001. Contemporary Economic Policy, 24(3), 459-474.

Sen, R. (2013). What do empirical studies say about economic growth and job creation in developing countries? Overseas Development Institute, 1.

Sengupta, P., \& Puri, R. (2018). Exploration of relationship between FDI and GDP: A comparison between India and its neighbouring countries. Global Business Review (2018): 0972150918760026.

Solow, R. (1956). A contribution to the theory of economic growth. The Quarterly Journal of Economics, 70, 65-94.

Sothan, S. (2017). Causality between foreign direct investment and economic growth for Cambodia. Cogent Economics \& Finance, 5(1), 1277.

Tan, B.W., \& Tang, C.F. (2016). Examining the causal linkages among domestic investment, FDI, trade, interest rate and economic growth in ASEAN-5 countries. International Journal of Economics and Financial Issues, 6(1), 214-220.

Tomi, S., \& D’Estaing, D.G. (2015). Foreign direct investment, economic growth and structural transformation: The case of West African Economies and Monetary Union Countries.

UNCTAD (2000). World Investment Report 2000. Cross-border Mergers and Acquisitions and Development, https://unctad.org/en/Docs/wir2000_en.pdf.

Vogiatzoglou, K., \& Nguyen, P.N.T. (2016). Economic openness and economic growth: A cointegration analysis for ASEAN-5 countries. The European Journal of Applied Economics, 13(2), 10-20.

World Bank (2019). https://databank.worldbank.org/reports.aspx? (accessed: 25.06. 2019). 